\title{
Writing History for the King: Henry II and the Politics of Vernacular Historiography
}

Review Number: 1974

Publish date: Thursday, 18 August, 2016

Author: Charity Urbanski

ISBN: 9780801451317

Date of Publication: 2013

Price: $£ 42.95$

Pages: 272pp.

Publisher: Cornell University

Publisher url: http://www.cornellpress.cornell.edu/book/?GCOI=80140100850170

Place of Publication: Ithaca, NY

Reviewer: John Gillingham

This is a book about two well-known dynastic verse histories commissioned by Henry II, the Roman de Rou by Wace and the Chronique des ducs de Normandie by Benoît de Sainte-Maure. Urbanski recognises that there's little that's remarkable about a dynastic ruler commissioning a history that celebrated the deeds of his ancestors, particularly in the case of a duke of Normandy in the later 12th century. Two histories of the Norman dukes had been composed in the 11th century, the De moribus et actis primorum Normanniae ducum by Dudo of St Quentin, and the Gesta Normannorum ducum by William of Jumièges; in the 12th century the latter had been twice revised, elaborated and extended, first by Orderic Vitalis and then by Robert of Torigni. Indeed Orderic's version of William's Gesta Normannorum ducum was one of Wace's main sources, while Robert's version was similarly employed by Benoît. But all these earlier works were in Latin, a medium in which Henry II, for all his vaunted education, showed no interest. By contrast he was the first ruler known to have sponsored histories written in French verse.

On the many problems of authorship and dates of composition, Urbanski accepts all the prevailing orthodoxies: Wace, a Norman canon of Bayeux and a prolific author who in his Roman de Brut had already produced a successful verse version of Geoffrey of Monmouth's British history, began to write c.1160 and stopped c.1174 when he lost Henry II's patronage. It then went to Benoît, already famous as the author of the Roman de Troie. The principal questions she asks are also familiar: 'Why did neither narrative reach their authors' present day? If Henry II sacked Wace, why did he do it, and in what ways did he expect Benoît to do better?' No one has devoted so many pages to these puzzles as she does here, though this is partly explained by her habit of reproducing extended passages from her primary sources in very long footnotes. In this all of this she is largely dependent, as she acknowledges, on the work of previous scholars such as Jean Blacker, Matthew Bennett, Jean-Guy Gouttebroze, Peter Damian-Grint, Glyn Burgess, Elisabeth Van Houts, Diana Tyson and Francoise Le Saux. It is generally assumed that Henry's support for history in the vernacular suggests that he wanted narratives that would be more widely comprehensible than Latin was, and in that in this sense his motives were political. But Urbanski's answers to the familiar questions involve her arguing for a much closer fit between Henry II's specific political aims and the commissions to Wace and Benoît than anyone before her had done. 
Beginning with the dubious generalisation that 'monarchs most often resorted to sponsoring history writing when the very survival of their dynasty was under threat', she claims that 'Henry's early years as king certainly qualified as such a time' (pp. 7, 40). This will surprise all those historians who, while recognising that the new king faced considerable problems in restoring royal authority after the civil war of Stephen's reign, had believed that at least the dynasty's survival was not one of them, given that by the end of his first five years on the throne he had three sons - Henry, Richard and Geoffrey - and there was not the glimmer of a challenge from the house of Blois. The following 15-page (pp. 41-55) potted history of Henry I's and Stephen's reigns hardly amounts to a demonstration that Wace received his commission at a time of dynastic crisis.

Urbanski argues that Henry wanted from Wace a history that addressed what she identifies as 'important threats' to his power: Norman disdain for his Angevin father, Geoffrey of Anjou; an abiding worry about the lack of clear rules of succession; and fear that his dynasty was too dependent upon the preferences of a powerful aristocratic establishment that was all too likely to see his governmental 'reforms' as burdensome innovations. Wace's narrative was expected to show that Henry was merely restoring the good government of his Norman ancestors while its genealogical format would help to inculcate hereditary right as the sole basis for the succession. There are serious problems with this. Her view that 'the lack of clear rules governing succession' posed a threat is an anachronistic assumption, ignoring the evidence that in societies where kings were expected to rule as well as reign, clear rules were just as likely to create problems. In any case there is no evidence either for Henry's alleged worries on this score or for an attempt by him to introduce a law of succession. Had he done so, it would have limited his own power to manipulate the succession. As his sons knew only well, it was a power he liked to use - though given her thesis it is perhaps not surprising that she chose not to draw attention to the plentiful chronicle evidence for him doing do. Indeed although it is certainly arguable that in the late 1160s and early 1170s Henry 'upset the established order by vigorously checking the power of his barons and interfering in the relations between his clergy and Rome', she offers very little detail about this. It is in any case hard to see what it would have to do with the task Wace set himself c.1160.

Another problem is that Urbanski's analysis of Wace's and Benoît's work focuses narrowly upon their coverage of the period after 1035, i.e. from the birth of William the Bastard onwards, presumably on the grounds that it was Wace's ambivalent treatment of the Norman Conquest as well as his apparent support for the 'wrong' side in the war between Henry I and Robert Curthose that led to Henry II sacking him. This is certainly the usual explanation, to which she adds a twist or two, on Caen's surrender to Henry I, for example - oddly, her bibliography does not contain her own article on the subject (1) - and the nice speculation that Wace's most critical remarks may have been added after his services had been dispensed with. It has long been observed that Benoît was much more diplomatic in what he wrote about William I, Henry I and Henry II than Wace had been. But in a book entirely devoted to their historical work it seems unambitious, if not downright perverse, to ignore the greater part of their histories. Her focus on the post1035 period means that she takes no account of the eight thousand or so lines (out of a total of nearly 17,000) Wace devoted to the pre-1035 dukes from Rollo (Rou) onwards. As for the Chronique des ducs de Normandie, Benoît managed to write more than 33,000 lines before he began to tell the story of the Bastard, and in all wrote less than another 12,000 lines before he too gave up - long before reaching Henry II's reign.

Urbanski's case that both authors had been instructed to legitimise Henry II's rule by showing that he was merely following the good custom of his predecessors required that she also take into consideration their presentation of the first six dukes, not merely the last three or four. Had she done this, she could have brought in relatively unfamiliar material as a way of shedding further light in these old problems. How, for example, might her belief that Henry's attempts to improve the collection of revenues and administration of justice subjected the barons to 'unwelcome royal scrutiny' (p. 63) mesh with Wace's portrait of Duke Richard II (r. 996-1026)? Although this duke was, according to Wace, called 'li bons Richard' on account of his goodness, nobility, valour and largesse (part 3, 1l., 774-8), he regularly shut himself away in a high tower and allowed no one to see him for a week on end while he went over his accounts with the officials and tax- 
collectors whom he had specifically summoned for that purpose, (part 3, 11., 1995-2008). No doubt this image of a good Norman duke can be fitted into her scheme, but it is symptomatic of a lack of ambition on her part that she did not try, instead remaining content to stay on the already much analysed ground of the years after 1035.

A more ambitious approach might also have led her to engage with Laura Ashe's attractive thesis that the time for a celebration of Normanitas was past, and that this helps to explain both Wace's unease with the whole project and Benoît's relative lack of success. But although Ashe's Fiction and History in England, 1066-1200 (2) is listed in the bibliography, there is no sign that it has provided any food for thought. Had it done, Urbanski might have broadened her primary source material by including two vernacular prose histories, the inter-related early 13th-century Chronique de Normandie and Histoire des ducs de Normandie et rois d'Angleterre (works on which Gregory Fedorenko has recently shed fresh light, both in his Cambridge Ph.D. thesis and in an article in Anglo-Norman Studies (3)). But her own take on the Norman histories of Wace and Benoît is a curiously Anglo-centric one (pp. 23-35) and, despite appealing (pp. 17-22) to Gabrielle Spiegel's discussion of verse and prose histories (including the Histoire des ducs), she limited herself to the later sections Wace and Benoit. All in all, a book that hopes to provide new-ish answers to old questions, but fails to convince, in part because it stays too long on narrow and well-trodden paths.

1. Charity Urbanski, 'Apology, protest, and suppression: interpreting the Surrender of Caen (1105)', Haskins Society Journal, 19 (2007).

2. Laura Ashe, Fiction and History in England, 1066-1200 (Cambridge, 2007).

3. Gregory Fedorenko, 'The thirteenth-century Chronique de Normandie', Anglo-Norman Studies, 35, Proceedings of the Battle Conference 2012 (2012-13).

The author wishes to thank the reviewer for his generosity in offering his considered opinion and refers interested parties to the work in question.

Source URL:https://reviews.history.ac.uk/review/1974

\section{Links}

[1] https://reviews.history.ac.uk/item/158343 